\title{
Modification of Extraction Methods on Determining Simeticone Suspension Using FTIR Method
}

\section{Ida Musfiroh*, Aliya N. Hasanah, Gia A. Faradiba, Ida Ayumiati, Mutakin Mutakin, Muchtaridi Muchtaridi}

\author{
Department of Pharmaceutical Analysis and Medicinal Chemistry, Faculty of Pharmacy, \\ Universitas Padjadjaran
}

Submitted 7 July 2019; Revised 8 October 2019; Accepted 8 October 2019; Published 18 October 2019

*Corresponding author: ida.musfiroh@unpad.ac.id

\begin{abstract}
Antacids dosage form are a class of drugs used to chemically bind and neutralize stomach acid. Simethicone is one of the antacids that works as an antiflatulant. In an effort to guarantee the quality of a preparation, a valid analysis method is needed that meets the validation parameters. The aim of this study is to modify of extraction method of the simethicone content of suspension samples using the FTIR method. The modification of simethicone extraction from suspension preparations with toluene solvents and hydrochloric acid $3.35 \mathrm{~N}(2: 5)$ has been carried out. The analysis method was validated by determination of precision, accuracy, limit of detection (LOD), and limit of quantification (LOQ) at wave number $1261 \mathrm{~cm}^{-1}$ and determination of the content of samples of simethicone suspension. The results showed that linearity parameters with a correlation coefficient of 0.997 in a concentration range of 1000-10,000 ppm, precision with a value of KV $<2 \%$, LOD and LOQ, respectively 378.97 and $1250.59 \mathrm{ppm}$. The results of the determination of simethicone suspension samples indicate that this method met the requirements of the validation parameters.
\end{abstract}

Keywords: antacid, infrared spectrophotometry, simethicone, validation

\section{Modifikasi Metode Ekstraksi pada Penetapan Kadar Suspensi Simetikon dengan Metode FTIR}

\begin{abstract}
Abstrak
Sediaan antasida merupakan golongan obat yang digunakan untuk mengikat secara kimiawi dan menetralkan asam lambung. Simetikon merupakan salah satu antasida yang bekerja sebagai antiflatulan. Dalam upaya menjamin kualitas suatu sediaan maka dibutuhkan metode analisis yang valid dan memenuhi parameter validasi. Penelitian ini bertujuan untuk melakukan modifikasi metode ekstraksi pada penetapan kadar simetikon dari sampel suspensi dengan metode FTIR. Metode meliputi metode ekstraksi simetikon dari sediaan suspensi yang dimodifikasi dengan pelarut toluen dan asam hidroklorida (2:5) 3,35 N. Validasi metode yang meliputi penentuan presisi, akurasi, limit of detection (LOD), dan limit of quantification (LOQ) pada bilangan gelombang $1261 \mathrm{~cm}^{-1}$ dan penetapan kadar dari sampel sediaan suspensi simetikon. Hasil penelitian menunjukkan parameter linieritas dengan koefisien korelasi 0,997 dalam rentang konsentrasi 1000-10.000 ppm, presisi dengan nilai $\mathrm{KV}<2 \%$, LOD dan LOQ berturut-turut yaitu 378,97 dan 1250,59 ppm. Hasil penetapan kadar simetikon dalam suspensi menunjukkan bahwa metode ini memenuhi persyaratan parameter validasi.
\end{abstract}

Kata Kunci: antasida, simetikon, spektrofotometri inframerah, validasi 


\section{Pendahuluan}

Antasida adalah produk obat yang pada pemberian oral menetralkan asam lambung berlebih dan menurunkan keasaman isi lambung. ${ }^{1}$ Antasida menetralkan asam yang menyebabkan beberapa produk yang menghasilkan senyawa larut. Tarif dan kapasitas penetralan juga terpengaruh di hadapan asam organik, pepton polipeptida. ${ }^{2,3}$ Antasida digunakan secara luas untuk menghilangkan heart burn dan dispepsia, dan gejala gastrointestinal yang non spesifik lainnya, tidak aman digunakan untuk penderita gangguan ginjal karena dapat menyebabkan alkalosis dan komplikasi. ${ }^{1}$

Simetikon merupakan agen antifoaming yang menurunkan tegangan permukaan gelembung gas dengan tidak mengurangi atau mencegah pembentukan gas dalam saluran pencernaan, melainkan meningkatkan pengeluaran gas dari tubuh. ${ }^{4}$ Simetikon sepenuhnya termetilasi dan biasa digunakan untuk menurunkan tegangan permukaan dari gas atau gelembung udara. Sifat anti-foamingnya telah dieksploitasi selama prosedur endoskopi sejak tahun 1978.5 Simetikon mengandung kurang lebih 90,5 - 99,0\% dari PDMS (polydimethylsiloxane) dan 4 - 7\% dari $\mathrm{SiO}_{2}{ }^{6}$

Validasi merupakan dasar dari kontrol kualitas di laboratorium, dan merupakan salah satu bagian dari sistem mutu regulasi yang menggabungkan QA dan QC. Ketika metode baru diimplementasikan di laboratorium, metode tersebut harus divalidasi ulang. Validasi juga diperlukan ketika metode standar yang ada dimodifikasi atau diubah, atau ketika metode yang ada diterapkan pada matriks sampel yang berbeda secara signifikan dari metode awal. Validasi metode berfungsi menyeimbangkan jumlah validasi untuk memenuhi standar USP dan FDA. Validasi metode adalah salah satu bagian dari proses validasi secara keseluruhan yang mencakup setidaknya empat langkah yang berbeda: (1) validasi perangkat lunak, (2) validasi / kualifikasi instrumen, (3) validasi metode, dan (4) validasi sistem, dan masing-masing langkah ini penting untuk keberhasilan keseluruhan proses. Validasi diatur oleh FDA dan dua referensi utama yaitu cGMP dan ISO 9000, juga dua pedoman yang paling penting yaitu USP Bab 1225: Validasi Metode kompendium dan ICH Guidelines. ${ }^{7}$

Analisis simetikon telah dilaporkan dengan beberapa metode yaitu diantaranya kromatografi cair kinerja tinggi fasa terbalik, ${ }^{8}$ kromatografi eksklusi ukuran, ${ }^{9}$ kromatografi gas. ${ }^{10}$ Dalam Farmakope Indonesia dan United States Pharmacopeia, analisis simetikon dilakukan dengan metode Fourier Transform Infra Red (FTIR). Metode FTIR memiliki tingkat spesifisitas yang baik dibanding metode spektroskopi lain karena dapat mendeteksi fingerprint suatu struktur senyawa. ${ }^{11}$ Rohman dkk (2013) telah melaporkan suatu metode analisis simetikon dalam sediaan suspensi dan tablet hisap, menggunakan proses ekstraksi dalam pelarut toluen: $\mathrm{HCl} 6 \mathrm{~N}$ dengan metode FTIR. ${ }^{12}$

\section{Fourier Transform Infrared}

Spectroscopy (FTIR) telah muncul sebagai teknik analisis penting dalam ilmu farmasi. ${ }^{13}$ Parameter validasi FTIR adalah pengulangan dari sistem (presisi), akurasi, rentang linear, batas deteksi (LOD) dan batas kuantifikasi (LOQ). FTIR adalah teknik analitis untuk molekul organik, dengan rentang IR $(4000 \mathrm{~cm}$ 1- $400 \mathrm{~cm}^{-1}$ ) yang menginformasikan tentang struktur dan gugus fungsi dalam analit. FTIR dapat digunakan secara kuantitatif, sebagai energi yang diserap pada panjang gelombang tertentu sebanding dengan jumlah obligasi terkait energi, sehingga dengan konsentrasi yang lebih besar dari analit lebih banyak energi akan diserap. ${ }^{14}$

USP menjelaskan metode analisis simetikon dalam sediaan emulsi dengan FTIR melalui proses ekstraksi dengan pelarut toluen dan asam $\mathrm{HCl}$ (2:5). ${ }^{6}$ Sementara itu Rohman dkk (2013) telah menjelaskan metode analisis simetikon dalam sediaan suspensi dengan metode FTIR melalui proses ekstraksi sampel dengan pelarut toluen: $\mathrm{HCl} 6 \mathrm{~N} .{ }^{12}$ Penambahan $\mathrm{HCl}$ dalam proses ekstraksi bertujuan untuk menetralkan komponen-komponen basa untuk membentuk garam yang larut dalam air, sehingga akan mudah dipisahkan dengan simetikon yang bersifat non polar. Dalam penelitian ini dilakukan modifikasi metode 
ekstraksi dalam analisis simetikon pada sampel sediaan suspensi dengan metode FTIR menggunakan pelarut toluen dan $\mathrm{HCl}$ 2:5 (3,35 $\mathrm{N})$. Metode analisis simetikon dalam sediaan suspensi ini dikembangkan dengan modifikasi konsentrasi $\mathrm{HCl}$ lebih rendah sehingga lebih efisien dalam proses analisisnya. Modifikasi ekstraksi ini kemudian dilanjutkan dengan validasi metode analisis kuantitatif meliputi parameter linearitas, sensitivitas, LOD, LOQ, akurasi dan presisi. Penelitian ini merupakan suatu pengembangan metode analisis simetikon dalam sediaan suspensi sehingga dapat digunakan sebagai alternatif metode analisis simetikon dalam sediaan suspensi di laboratorium pengujian.

\section{Metode}

2.1. Alat

Alat yang digunakan dalam penelitian ini adalah alat-alat gelas yang umum digunakan laboratorium analisis, pipet tetes, mikropipet (Socorex accura 825 autocavable), neraca analitis (Sartorius), vortex (Vortex Mixer VM-300), shaker (IKA HS Basic shecker), tabung sentrifugasi, sentrifugator (Hettich centrifugen), vial, dan FTIR (Fourier Transform Infra Red) Prestige-21 Shimadzu.

\subsection{Bahan}

Bahan yang digunakan dalam penelitian ini adalah simetikon standar USP, asam klorida (Merck), toluen, aqua destilata, natrium sulfat anhidrat (Merck), suspensi plasebo antasida yang diperoleh dari laboratorium Farmasetika Fakultas Farmasi UNPAD, dan sampel suspensi antasida.

\subsection{Pembuatan larutan standar simetikon \\ Dibuat larutan stok dengan konsentrasi} 100.000 ppm, $5 \mathrm{~mL}$ simetikon standar USP dilarutkan dalam labu ukur $50 \mathrm{~mL}$ menggunakan pelarut toluen. Larutan stok tersebut kemudian digunakan untuk membuat satu seri larutan standar kerja yang digunakan untuk membuat kurva kalibrasi.

\subsection{Pembuatan asam klorida (2:5)}

Asam klorida dibuat dengan cara melarutkan 2 bagian asam klorida $36 \%$ dalam 5 bagian larutan $(200 \mathrm{~mL}$ asam klorida diencerkan dengan $300 \mathrm{~mL}$ aqua destillata).

\subsection{Ekstraksi simetikon dalam sampel suspensi \\ Metode ekstraksi menggunakan} metode yang dijelaskan dalam USP (2009) dan Rohman dkk (2013) dengan modifikasi perbandingan pelarut yaitu toluen : $\mathrm{HCl}$ 3,35 N. Sebanyak $10 \mathrm{~mL}$ suspensi antasida dimasukkan ke dalam labu erlenmeyer bertutup. $^{6,12} \mathrm{Ke}$ dalamnya ditambahkan 25 $\mathrm{mL}$ toluen dan $50 \mathrm{~mL}$ asam klorida $3,35 \mathrm{~N}$, dikocok selama 5 detik, kemudian dishaker pada $210 \mathrm{rpm}$ selama 30 menit. Selanjutnya campuran disentrifugasi pada $1500 \mathrm{rpm}$ selama 40 menit. Fase organik dipisahkan lalu dimasukkan ke tabung sentrifugasi lain yang telah berisi $1 \mathrm{~g}$ natrium sulfat anhidrat. Campuran disentrifugasi kembali pada $1500 \mathrm{rpm}$ selama 10 menit, kemudian filtrat dipipet ke dalam vial dan diukur dengan menggunakan FTIR. Prosedur tersebut juga digunakan untuk ekstraksi blanko.

\subsection{Pengukuran spektrum IR simetikon standar}

Pada penentuan kondisi optimum ini akan menentukan bilangan gelombang yang dapat memberikan respon analit terhadap serapan yang linier. Larutan baku simetikon diukur dengan FTIR pada tiga bilangan gelombang maksimal, dan serapan simetikon baku pada bilangan gelombang yang dapat memberikan linieritas terbaik akan ditetapkan sebagai bilangan gelombang optimum untuk pengukuran.

2.7. Validasi metode analisis simetikon
dengan metode spektrofotometri
inframerah
Validasi metode analisis melalui pengukuran parameter linearitas, sensitivitas yang terdiri atas LOD dan LOQ, akurasi, presisi.

\subsubsection{Linearitas}

Linearitas dilakukan dengan membuat 6 variasi konsentrasi simetikon (SMT) standar USP pada rentang konsentrasi 1000 
-10000 ppm, kemudian larutan diukur dengan menggunakan FTIR. Parameter linearitas ditentukan dengan menghitung koefisien korelasi (r) dari kurva regresi linear. Pada penentuan linieritas ini diukur pada tiga bilangan gelombang yang dihasilkan pada penetapan kondisi optimum. Bilangan gelombang yang dapat menghasilkan kurva regresi linear dengan nilai $r$ tertinggi digunakan untuk penetapan parameter validasi dan penetapan kadar sampel.

\subsubsection{Sensitivitas}

Sensitivitas ditentukan dengan menguji sampel blanko yang ditambahkan dengan satu konsentrasi SMT standar yaitu 60 ppm. Nilai LOD dihitung menggunakan persamaan: $\mathrm{Y}_{\text {LOD }}=\mathrm{Y}_{\text {blank }}+3 \mathrm{SD} . \mathrm{Y}_{\text {blank }}$ adalah respon untuk sampel blanko. SD adalah standar deviasi yang diperoleh dari 10 absorbansi pengukuran sampel. Nilai $\mathrm{Y}_{\text {LOD }}$ digunakan untuk mendapatkan nilai $\mathrm{x}$ (konsentrasi) yang dihitung berdasarkan persamaan kurva kalibrasi selama penentuan linearitas. Nilai $x$ adalah LOD. Selain itu, nilai LOQ dapat dihitung dengan rumus: $\mathrm{LOQ}=3,33 \times \mathrm{LOD} .{ }^{12}$

\subsubsection{Presisi}

Uji presisi dilakukan dengan menentukan keterulangan, dengan cara mengukuran 6 kali sampel blanko yang ditambahkan dengan standar SMT dengan kondisi analisis yang sama, juga dilakukan pengukuran presisi inter day. Konsentrasi yang digunakan yaitu 5000 ppm. Parameter keterulangan ditentukan dengan menghitung nilai standar deviasi relatif (RSD). Selanjutnya, presisi inter day dihitung dengan membandingkan hasil yang diperoleh dari uji keterlulangan yang berbeda dalam tiga hari yang berbeda.

\subsubsection{Akurasi}

Uji akurasi ditentukan dengan metode standar adisi pada tiga kelompok sampel dengan konsentrasi 50, 100 and $150 \%$ dan pengulangan masing masing tiga kali. Uji dilakukan juga terhadap blanko.

\subsection{Analisis simetikon dalam sampel} antasida

Sampel antasida yang dijual di pasaran Merk A diambil sebanyak $10 \mathrm{~mL}$ dan dimasukkan ke labu Erlenmeyer bertutup. Ditambahkan $25 \mathrm{~mL}$ toluen dan dilakukan proses ekstraksi dengan perlakuan yang sama seperti standar dan larutan spike. Setelah didapat fase organiknya, fase organik tersebut diukur dengan menggunakan IR. Proses pengukuran menggunakan alat FTIR (IR prestige-21) Shimadzu, dilakukan dengan cara mengukur blanko terlebih dahulu, lalu dilanjutkan dengan larutan uji. Pada spektrum absorbansi yang dihasilkan diamati puncak pada bilangan gelombang $1261 \mathrm{~cm}^{-1}$.

\section{Hasil}

3.1. Hasil optimasi metode analisis dengan

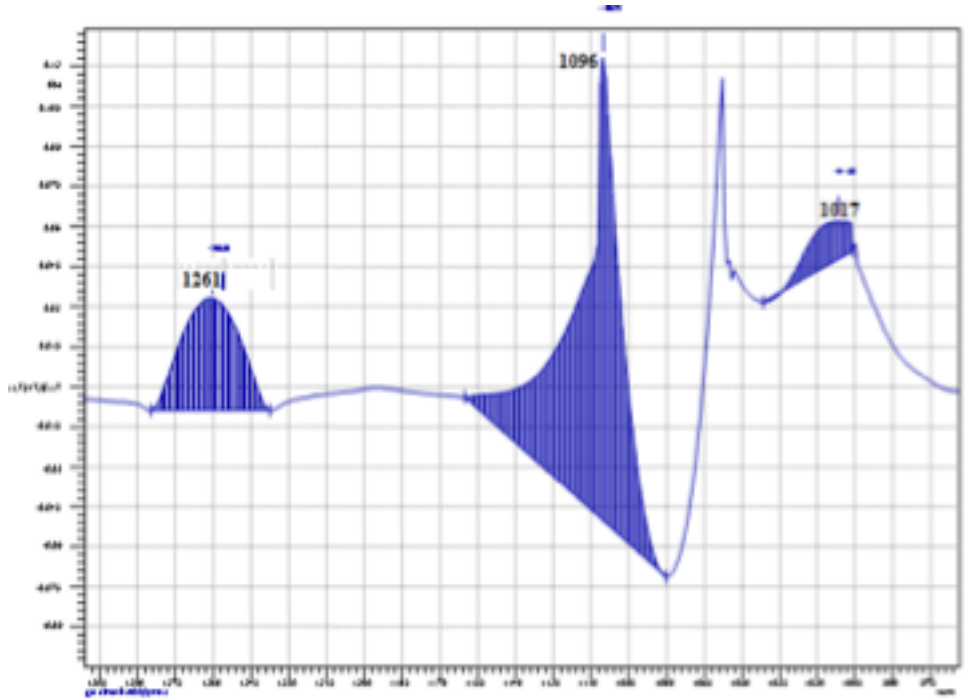

Gambar 1. Spektrum simetikon pada bilangan gelombang 1261, 1096, dan $1017 \mathrm{~cm}^{-1}$ 
Tabel 1. Hasil analisis sampel untuk menentukan repeatability dan intermediet precision (inter day) $(\mathrm{n}=6)$

\begin{tabular}{ccccc}
\hline Hari ke & $\begin{array}{c}\text { Konsentrasi } \\
\text { sebenarnya }(\mathrm{ppm})\end{array}$ & $\begin{array}{c}\text { Konsentrasi yang } \\
\text { diperoleh (ppm) }\end{array}$ & $\begin{array}{c}\text { Repetability } \\
(\% \mathrm{RSD})\end{array}$ & $\begin{array}{c}\text { Intermediet } \\
\text { Precision (\%RSD) }\end{array}$ \\
\hline 1 & 5000 & 5156,36 & 1,71 & \\
3 & 5000 & 5774,98 & 1,64 & 1,72 \\
8 & 5000 & 5844,66 & 1,82 & \\
\hline
\end{tabular}

spektrofotometer inframerah

Data absorbansi larutan baku simetikon diperoleh tiga penanda serapan maksimum yaitu pada bilangan gelombang 1096, 1017 dan $1261 \mathrm{~cm}^{-1}$. Data spektrum serapan simetikon baku dan sampel suspensi simetikon ditunjukkan pada Gambar 1 dan 2.

\subsection{Linearitas}

Parameter linearitas, dilakukan dengan mengukur enam konsentrasi, yang dibuat dari larutan stok standar $100.000 \mathrm{ppm}$. Variasi konsentrasi yang digunakan yaitu $1.000 \mathrm{ppm}$, 2.000 ppm, 4.000 ppm, 6.000 ppm, 8.000 ppm, dan $10.000 \mathrm{ppm}$. Larutan standar yang sudah dibuat dengan variasi konsentrasi tersebut diekstraksi lalu diukur dengan menggunakan FTIR. Dari data tersebut didapatkan nilai koefisien korelasi pada bilangan gelombang $1261 \mathrm{~cm}^{-1}, 1096 \mathrm{~cm}^{-1}$, dan $1017 \mathrm{~cm}^{-1}$ berturutturut adalah 0,9985; 0,9969; dan 0,9979. Dalam linearitas, parameter yang digunakan adalah nilai koefisien korelasi. Nilai koefisien korelasi yang baik yaitu mendekati 1 . Oleh karena itu maka dipilih bilangan gelombang
$1261 \mathrm{~cm}^{-1}$ karena memiliki nilai koefisien korelasi (r) yang paling tinggi yaitu 0,997 dan peak yang dihasilkan memiliki bentuk yang paling baik (Gambar 3).

\subsection{Sensitivitas}

Hasil simpangan baku dari pengukuran linearitas digunakan untuk menghitung nilai LOD dan LOQ. Setelah LOD dievaluasi, didapatkan hasil nilai LOD sebesar 378,97 ppm. $Y_{\text {blank }}$ adalah rata-rata respon untuk sampel blanko. SD adalah standar deviasi yang diperoleh dari 10 absorbansi sampel hasil pengukuran sampel dengan konsentrasi 60 ppm. Setelah itu, nilai LOQ dihitung dengan rumus: $\mathrm{LOQ}=3,33 \times \mathrm{LOD}$, didapatkanlah nilai LOQ sebesar 1250,59 ppm.

\subsection{Presisi}

Presisi dievaluasi dengan melakukan prosedur repeatibility dan intermediet precision. Repeatability dapat dinilai dengan menggunakan 2 cara, yang pertama yaitu dengan minimal 9 penentuan mencakup rentang yang ditentukan untuk prosedur



Gambar 2. Spektrum sampel suspensi antasida pada bilangan 1261, 1096, dan $1017 \mathrm{~cm}^{-1}$ 
Tabel 2. Hasil penentuan akurasi $(\mathrm{n}=10)$

\begin{tabular}{ccccc}
\hline $\begin{array}{c}\text { Konsentrasi } \\
\text { spike (\%) }\end{array}$ & $\begin{array}{c}\text { Konsentrasi } \\
\text { sebenarnya }(\mathrm{ppm})\end{array}$ & $\begin{array}{c}\text { Konsentrasi yang } \\
\text { diperoleh }(\mathrm{ppm})\end{array}$ & Recovery (\%) & RSD (\%) \\
\hline 0 & 4000 & 3237,69 & - & - \\
50 & 6000 & 5349,46 & 89,15 & 2,42 \\
100 & 8000 & 7462,84 & 93,27 & 2,63 \\
150 & 10000 & 9568,81 & 95,69 & 0,70 \\
& & Range & $89,15-95,69$ & \\
\hline
\end{tabular}

(misalnya, 3 konsentrasi / 3 ulangan masing-masing); atau minimal 6 penentuan pada 100 persen dari konsentrasi uji. Pada penelitian ini, dilakukan uji repeatability dengan menggunakan 1 konsentrasi dengan 6 ulangan. Uji repeatability tersebut diulang dalam 3 hari yang berbeda untuk mengetehui intermediet precision (inter day). Dilakukan pengujian pada hari ke 1, ke 3 dan ke 8 dengan hasil sebagai berikut. Data lengkap pada masing-masing hari dapat dilihat pada Tabel 1.

\subsection{Akurasi}

Akurasi dinilai dengan menggunakan minimal 9 sampel dengan 3 tingkat konsentrasi yang mencakup kisaran tertentu (misalnya, 3 konsentrasi/3 ulangan masing-masing total prosedur analitis). Akurasi dilaporkan sebagai persen perolehan kembali dengan uji jumlah tambahan (spike) dalam sampel atau sebagai perbedaan antara rata-rata dan nilai sebenarnya yang diterima. Variasi konsentrasi yang dipilih yaitu 50\%, 100\% dan $150 \%$. Sampel yang digunakan memiliki konsentrasi $4.000 \mathrm{ppm}$, sehingga konsentrasi yang ditambahkan yaitu 2.000 ppm, 4.000 ppm, dan 6.000 ppm seperti yang ditunjukkan pada Tabel 2.

3.6. Analisis simetikon dalam sampel antasida menggunakan spektrofotometer inframerah

Sebanyak 10 sampel antasida suspensi (Merk A) dianalisis dengan menggunakan prosedur ekstraksi yang sama dengan standar dan diukur dengan menggunakan FTIR. Hasil yang didapatkan ditunjukkan pada Tabel 3 dengan nilai $\mathrm{SD}<2 \%$.

\section{Pembahasan}

Ekstraksi cair cair dalam penelitian ini digunakan sebagai cara untuk memisahkan simetikon dari komponen suspensi yang dapat mengganggu pada saat kuantifikasi maupun deteksi simetikon dengan FTIR. Pada prosedur ekstraksi simetikon ini digunakan toluen dan $\mathrm{HCl}$ (dalam air 2:5) sebagai pelarut berdasarkan kelarutan simetikon (USP, 2009). Modifikasi ekstraksi dilakukan dengan menggunakan konsentrasi $\mathrm{HCl} 3,35 \mathrm{~N}$ atau $\mathrm{HCl}(36 \%)$ : air 2:5, sedangkan penelitian sebelumya yang dilakukan Rohman dkk (2013) menggunakan konsentrasi yang lebih pekat yaitu 6 N. ${ }^{12}$ Dan hasil dari ekstraksi ini kemudian digunakan untuk pengujian

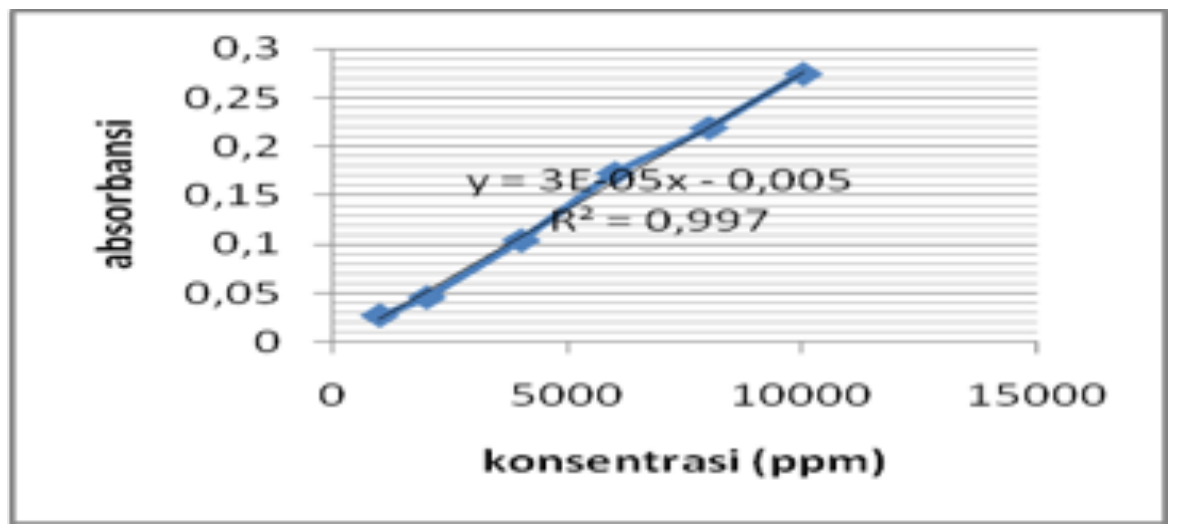

Gambar 3. Linearitas simetikon standar pada bilangan gelombang $1261 \mathrm{~cm}^{-1}$ 
Tabel 3. Hasil analisis sampel sediaan simetikon suspensi

\begin{tabular}{cccc}
\hline Sampel & Absorbansi & Konsentrasi $(\mathrm{ppm})$ & \% Kadar \\
\hline X1 & 0,068086 & 2608,67 & 70,11 \\
X2 & 0,064308 & 2474,88 & 66,51 \\
X3 & 0,066568 & 2554,93 & 68,66 \\
X4 & 0,059551 & 2306,45 & 61,99 \\
X5 & 0,064301 & 2474,66 & 66,51 \\
X6 & 0,058894 & 2283,18 & 61,36 \\
X7 & 0,071502 & 2729,64 & 73,36 \\
X8 & 0,064112 & 2467,97 & 66,33 \\
X9 & 0,052613 & 2060,77 & 55,39 \\
X10 & 0,058624 & 2273,63 & 61,11 \\
Rata-rata & 0,0628559 & 2423,478 & 65,13 \\
SD & 0,005488456 & 1,94 & \\
\hline
\end{tabular}

validasi metode analisis dan analisis kadar simetikon dalam sediaan suspensi cair. Dalam prosedur ekstraksi, setelah penambahan toluen sebanyak $25 \mathrm{~mL}$, ditambahkan $50 \mathrm{~mL}$ asam klorida yang sudah diencerkan ke dalam labu ekstraksi. Fungsi asam klorida ini adalah sebagai fasa yang melarutkan senyawa polar yang terdapat pada suspensi antasida. ${ }^{12}$ Setelah penambahan pelarut dilakukan pengocokan menggunakan shaker selama 30 menit pada kecepatan $210 \mathrm{rpm}$. Setelah itu dilakukan proses sentrifugasi selama 40 menit dengan kecepatan $1500 \mathrm{rpm}$. Proses sentrifugasi ini bertujuan untuk memisahkan fase polar dan non polar serta mengendapkan padatan yang terdispersi di dalam suspensi antasida agar tidak ikut terbawa ke dalam fase toluen. Fase toluen dipisahkan dan dipindahkan ke dalam tabung sentrifugasi lain yang berisi 1 gram natrium sulfat anhidrat lalu disentrifugasi kembali selama 10 menit. Proses sentrifugasi menggunakan natrium sulfat anhidrat ini bertujuan untuk menyerap air yang mungkin ikut terbawa sehingga mengganggu pengukuran karena adanya serapan gugus hidroksida pada air. Larutan hasil sentrifugasi tersebut dipisahkan dari natrium sulfat dengan cara dipipet ke dalam vial.

Pada hasil optimasi metode analisis menggunakan spektrofotometer inframerah, absorbansi larutan baku simetikon diperoleh tiga serapan maksimum yaitu pada bilangan gelombang 1096, 1017 dan $1261 \mathrm{~cm}^{-1}$. Hal ini selaras dengan penelitian sebelumnya yang menyatakan bahwa simetikon yang dilarutkan dalam toluen memiliki bilangan gelombang 1097; 1013, dan $1261 \mathrm{~cm}^{-1} .^{12}$ Sedangkan, USP 32 menjelaskan pengukuran simetikon dalam sediaan emulsi menggunakan bilangan gelombang $1257 \mathrm{~cm}^{-1}, 6$ perbedaan ini dapat disebabkan karena matriks sediaannya yang berbeda antara emulsi dan suspensi.

Hasil pengujian linearitas didapatkan nilai koefisien korelasi pada bilangan gelombang $1261 \mathrm{~cm}^{-1}, 1096 \mathrm{~cm}^{-1}$, dan 1017 $\mathrm{cm}^{-1}$ berturut-turut adalah 0,9985; 0,9969; dan 0,9979. Dalam hal ini dipilih bilangan gelombang $1261 \mathrm{~cm}^{-1}$ karena memiliki nilai koefisien korelasi (r) yang paling tinggi dan peak dengan bentuk yang paling baik. Nilai tersebut memenuhi persyaratan linearitas yaitu koefiseien korelasi tidak kurang dari $0,99 .{ }^{15}$ Hasil penelitian ini selaras dengan penelitian sebelumnya, dimana metode ekstraksinya menggunakan $\mathrm{HCl} 6 \mathrm{~N}$ dengan nilai koefisien linearitas masing masing adalah 0,9989; 0,9858 dan 0,9922 yang diukur pada panjang gelombang 1261, 1097 dan $1013 \mathrm{~cm}^{-1} .^{12}$

Sementara itu, pengujian sensitivitas metode analisis pada penelitian ini ditentukan berdasarkan nilai batas deteksi (LOD) dan batas kuantifikasi (LOQ). LOD merupakan kadar analit yang terkecil yang dapat dideteksi dibandingkan dengan respon blanko atau noise, sedangkan LOQ adalah kadar analit terkecil yang dapat diukur secara kuantitatif 
hingga memenuhi presisi.

Selanjutnya, pengujian parameter presisi diukur sebagai simpangan baku atau simpangan baku relatif (koefisien variasi). Kriteria seksama diberikan jika metode memberikan simpangan baku relatif atau koefisien variasi $2 \%$ atau kurang. Hasil pengujian menunjukkan simpangan baku relatif (\%RSD) pada hari pertama sebesar $1,71 \%$, pada hari ke 3 sebesar 1,64\%, dan pada hari ke 8 sebesar $1,82 \%$. Sedangkan hasil perhitungan intermediet precision menunjukkan nilai simpangan baku relatif sebesar $1,72 \%$, nilai tersebut memenuhi persyaratan yaitu $<2 \%$.

Pada pengujian akurasi dalam penelitian ini dilakukan pengukuran 10 sampel blanko yang ditambahkan dengan konsentrasi terkecil yang dapat diukur. ${ }^{16}$ Sampel blanko yang dibuat untuk pengujian ini dispike dengan konsentrasi $60 \mathrm{ppm}$. Setelah itu, sampel tersebut diekstraksi dan diukur dengan menggunakan FTIR. Pengujian akurasi dari ketiga variasi konsentrasi yang digunakan menunjukkan hasil yang memenuhi syarat, dimana sebagaimana tertera dalam USP bahwa konsentrasi simetikon di dalam sediaan suspensi adalah dalam rentang 85-115\%.

Pada analisis simetikon dalam sampel antasida dengan merk A menggunakan spektrofotometer inframerah yang telah divalidasi didapatkan nilai $\mathrm{SD}<2 \%$, namun jika dihitung terhadap kadar yang tertera pada komposisi produk maka hasil analisis menunjukkan kadar simetikon kurang dari $85 \%$, yaitu rata rata kadar simetikon dalam sampel $65,13 \%$. Hal ini dapat disebabkan karena adanya matriks dalam sampel yang berbeda dengan matriks pada sampel simulasi sehingga pada saat dilakukan ekstraksi terdapat analit yang tidak terbawa. Oleh karena itu disarankan untuk penelitian selanjutnya dilakukan analisis sampel dengan dari beberapa merek sediaan.

\section{Simpulan}

Hasil modifikasi metode ekstraksi analisis simetikon dalam sediaan suspensi menggunakan spektrofotometri FTIR telah memenuhi parameter validasi yaitu meliputi linearitas dengan nilai r sebesar 0,997, presisi dengan nilai simpangan baku relatif untuk repeatability dan intermediet precision kurang dari $2 \%$, serta LOD sebesar 378,97 ppm dan LOQ sebesar 1250,59 ppm dan penetapan kadar simetikon dalam sampel yaitu 2423,478 ppm dengan SD 1,94 \%.

\section{Ucapan Terimakasih}

Penelitian ini didanai oleh hibah penelitian unggulan Fakultas Farmasi Universitas Padjadjaran.

\section{Pustaka}

1. Rao G C., S., Sahoo N., K., Parhi R., Panigrahi N. Study On The Effectiveness Of Branded And Generic Antacid Suspension Forms. Journal of Pharmacy Research. Research Article. ISSN: 09746943. 2011, 4(3), 612-613

2. Flynn, C.A., Alnouti, Y., Reed, G.A., 2011. Quantification Of The Transporter Substrate Fexofenadine In Cell Lysates By Liquid Chromatography/Tandem Mass Spectrometry. Rapid Commun. Mass Spectrom. 25(16), 2361-2366.

3. Sapkal, N.P., Kilor, V.A., Shewale, B.D., Bhusari, K.P., Daud, A.S., 2010. Study of the complexation behaviour of fexofenadine with bcyclodextrin. Indian J. Pharm. Sci. 72 (3), 318-323.

4. Hassanuddin F., Kumar G.V., Haneef M.A. Validated High Performance Liquid Chromatography Method For Simultaneous Estimation Of Magaldrate and Simethicone In API and Tablet Dosage Form and Its Aplication To Forced Degradation Studies. International Journal of Pharmacy Review \& Research. 2018, 8 (1); 12-18.

5. Benmassaoud A., Parent J., CAG Position Statement: The Impact of Simethicone on Endoscope Reprocessing. Publication. Canada: McGill University Health Center. Division of Gastroenterology. 2017.

6. United States Pharmacopeial Convention. Simethicone emulsion. United States Pharmacopeial Convention: Interim Revision Announcement Official 1 January 2014. Available at http://www. 
usp.org/sites/default/files/usp_pdf/EN/ simethicone emulsion.pdf. 2013.

7. Swartz M., E., Krull I., S. Handbook of Analytical Validation. CRC Press. Taylor \& Francis Group. 2012.

8. Latha BM, Noorjahan MD, dan Madhkar A. A New RP-HPLC Method For The Simultaneous Estimation Of Magaldrate And Simethicone In Bulk And Tablet Dosage Form As Per Ich Guidelines. J Syn Natu Chem. 2018, 3(1): 31-34

9. Pienkowska MK. Size Exclusion Chromatography With Evaporative Light Scattering Detection As A Method For Speciation Analysis Of Polydimethylsiloxanes. III. Identification And Determination of Dimeticone And Simeticone In Pharmaceutical Formulations. J Pharm Biomed Anal. 2012, 58: 200-207

10. Acunha CFS dan Santos JHZ. An Analytical Method for Quantifying Dimethicone in a 30\% Simethicone Emulsion Using Gas Chromatography. Brazilian J. Anal. Chem. 2011 (6): 278285.

11. Rohman A. Application of FTIR Spectroscopy for Quality Control in Pharmaceutical Products: a Review.
Indonesian J. Pharm. 2012.23 (1): 1-8.

12. Rohman A, Musfiroh A, dan Wijaya EG. Quantitative determination of simethicone in antacid suspension and chewable tablet using FTIR spectroscopy. Global J. Pharmacol. 2013. 7(3): 270-275.

13. Patel Rakesh, Patel Charmi, Rajesh. K. S; Quantitative Analytical applications of FTIR Spectroscopy in Pharmaceutical and Allied Areas; J. Adv. Pharm. Edu. \& Res. 2014: 4(2): 145-57.

14. Riyanto, Nas S., W., Validation of Analytical Methods for Determination of Methamphetamine Using Fourier Transform Infrared (FTIR) Spectroscopy. Journal of Pharmacy and Biological Sciences. 2016, 11 (5); 51-59.

15. United Nations Office on Drugs and Crime (UNODC). Guidance for the validation of analytical methodology and calibration of equipment used for testing of illicit drugs in seized materials and biological specimens. United Nations Publication: New York. 2009.

16. Islam T, Ferdous S, Jain P, dan Reza HM. Method Development and Validation of Baclofen Mouth Dissolving Tablets by UV Spectroscopy. European J. of Appl. Sci. 2013. 5(1): 07-11. 